\title{
Notes and News from Members
}

A gratifying number of letters have been received from Blue Jay members who want to share with us their experiences of nature. We like to print excerpts from as many of these letters as possible.

Birds are always popular with our readers. Mrs. Osmund of WHITE BEAR, SASK., tells about the birds that especially thrilled r:er this past year-a Rose-breasted Grosbeak in spring, a Ruby-throated Hummingbird in August, and warblers, vireos and thrushes in fall migration. Cedar Waxwings are apparently rare birds at White Bear. With another winter upon us, Mrs. Ona Link of DAVIDSON, SASK., recalls the thirteen huddled Gray Partridge that made a round dark mass in the fresh snow only 10 feet from her window after a winter storm. This year's unseasonal early October snow brought a scolding House Wren into the house with some geraniums that were being rescued by Mrs. Keith Paton of OXBOW, who sends us many bird notes. Adolph Miller of FORGAN tells of Meadowlarks suffering in the storm. He counted 11 dead birds in a two-mile stretch of Highway \#44, along which he noted large numbers which appeared to be suffering from the cold and deep snow cover. Mr. Miller also mentions a junco-like bird seen feeding with juncos, which had a white head and white on the wings. We suggest that this was probably a partial albino. Albinos often occur, and Amelia Laskey of NASHVILLE, TENNESSEE, sent us a photo of albino Blue Jays because she thought the Blue Jay magazirie would be interested in them.

Another example of an albino is the white sandpiper seen by Mr. H. E. Mawson and A. T. Murray Evans of Dundurn near Kenaston, May 20, 1959, and reported to us by D. Murray, of LAIRD, SASK.

Another frequent contributor is $\mathbf{J}$. David Chandler of MASEFIELD, SASK. He wrote some time ago to describe a dramatic moment when he watched a mother antelope come to protect her fawn from a swooping Golden Eagle, and a recent letter asks for suggestions for controlling House Sparrows. Mr. Chandler has watched House Sparrows this year take over nesting sites of Eastern
Phoebes, Eastern Kingbirds, Western Kingbirds and Barn Swallows.

Mrs. E. A. Dodd of ERINFERRY, SASK., in the bush country south of Big River writes that there seemed to be more birds there this year. A quite unusual bird, that Mrs. Dodd thought might be a Poor-will, arrived on June 1 and rested there within sight of her window throughout the day. We would guess that the warblers Mrs. Dodd mentions were Myrtle Warblers rather than the very similar Audubon's, which would be well beyond their normal range at Erinferry. A colony of bats discovered in August prompts Mrs. Dodd to ask whether bats go south: to hibernate. It appears that they do, although hibernating bats have been found in Sask. (see Blue Jay, 17:78).

The variety of wildlife at CREELMAN, SASK., is described in a letter from S. N. Horner ... flickers nesting at tre farm in the old cottonwoods, gray squirrels apparently finding a home in a small 10 in. culvert lying under apple trees, and deer and the occasional elk wandering out of the Moose Mountain game preserve.

Jim Dubray of SWAN RIVER, MAN., has a young Horned Owl given him by a local boy who had been trying to raise it on milk and dog food. Although not yet fully developed (Oct. 14), the owl requires about $3 / 4$ pound of meat per day. People who have thought of raising young Horned Owls should read Richard Fyfe's article on the Hawk Men in this issue.

Among the clippings sent the Blue Jay recently by Cecilia Hill of NANAIMO, B.C., is one from the Birmingham Post, June 1, 1959, re: the protest made by the Birmingham and West Midland Bird Club against damage to the countryside by roadside spraying in Staffordshire. The club protests that this is the only county council in the country trat is continuing roadside spraying, and that nest sites of many birds are being laid bare at the height of the breeding season. Some time ago we had a stimulating letter on the topic of poison sprays and baits from Alvin Goetz, BLUFFTON, ALTA., who described himself as "not a professional naturalist or such but just 


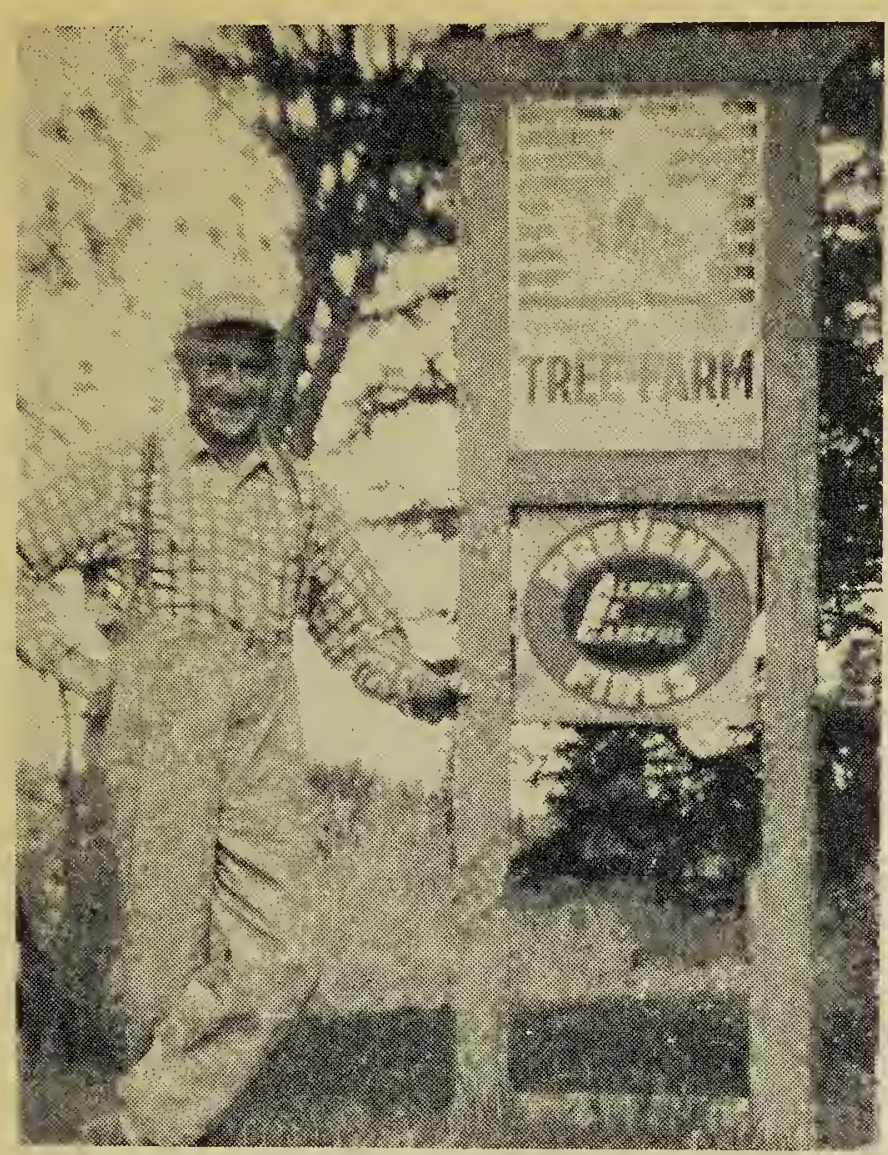

Stuart Francis at Spruce Dale Farm an ordinary farmer" aware of the dangers of poisoning wildlife and upsetting the balance of nature by the use of sprays and baits such as 1080 .

One of the letters, from Kathleen O'Drowski of PRINCE GEORGE, B.C., was accompanied by an account of a visit paid to Spruce Dale Farm, a farm of real interest to Blue Jay readers because this is $\mathrm{C}$. Stuart Francis' tree farm at Torch River. Kathleen visited her uncle's farm for a month in May after an absence of three years. From the moment she drove up the familiar lane over which the spruce trees clasped hands to form an arck, Kathleen began to enjoy again the delights of the farm in spring. She watched the trees come into leaf, went for evening walks in the pasture and spied a lone coyote coming out of the willows, noted the return of spring birds and especially the barn swallow (which she does not see in Prince George).

\section{The Saskatchewan Natural History Society}

\section{Annual Meeting, October 16-1\%, 1959}

\section{By Elizabeth Cruickshank, Recording Secretary}

From the moment Dr. A. J. Beddie, with his constant four-footed companion Zane, welcomed the members of the Saskatchewan Natural History Society to the lecture room of the Saskatchewan Training School until reluctant good-byes were said in the Canadian Room of the Harwood Hotel, expert planning and efficient carrying out of details was at all times evident in this year's annual meeting. The Natural History Society of Moose Jaw, the "Friendly City," outdid itself!

One rundred and two perscns registered for the business and programme sessions, among them more junior members than were present at any previous annual meeting. Some members were missing-the society in the last year suffered great loss in the passing of Cliff Shaw, a former editor of the Blue Jay, and Allan Hudson, a former director. In their memory, a two-minute silence was cbserved.

The programme began with a joint lecture by W. B. Hyshka and A. J. Rankin. Mr. Hyshka gave a talk with pictures on Old Wives Lake, showing and remarking on the nesting habits of the birds which live there. The most amazing picture ivas one of pelicans nesting among rose briar where the bushes had been stripped bare. Mr. Rankin's pictures were of the "Prairie Sahara." He stressed how conscious we are of water, the stabilization of wrich has now begun with the fulfilment of a 50-yearold dream in the building of the Outlook Dam. Pollution by oil, caustic soda and sewage of our waterways is a serious but solvable problem.

At the afterncon session, Thomas Kehoe, Curator of Archaeology and Ethnology at the provincial museum, with pictures explained how the arckacologist expects to reconstruct the history of tr.e past in Saskatchewan. Archaeological displays arranged in the meeting room aroused keen interest and much comment.

Elizabeth Cruickshank gave some of hel impressions of the A.O.U. meeting.

Resolutions presented at the meeting dealt with the following matters: a request for early development of a portion of the Moose Jaw Creek as a permanent wildlife sanctuary; request for permission to sell pictures of the habitat groups at the Museum; appreciation to the Conservation 